\title{
Sistem Penunjang Keputusan Pemilihan Motor Bekas Menggunakan Metode TOPSIS
}

\author{
Hendrikus ${ }^{1}$, Syarif Hidayatulloh ${ }^{2}$ \\ 1 Universitas Adhirajasa Reswara Sanjaya \\ e-mail: hendryxian@gmail.com \\ ${ }^{2}$ Universitas Adhirajasa Reswara Sanjaya \\ e-mail: syarif@ars.ac.id
}

\begin{abstract}
Abstrak
Kebutuhan akan alat transportasi merupakan sesuatu hal yang lumrah dan amat sangat dibutuhkan dalam kehidupan. Salah satu alat transportasi darat yang paling banyak digunakan oleh masyarakat di Indonesia adalah sepeda motor, karena selain irit jika dibandingkan dengan kendaraan bermotor roda empat, motor memiliki kelebihan bisa mencapai tempat tujuan lebih cepat. Metode yang digunakan adalah TOPSIS yang akan menentukan peringkat opsi berdasarkan total pada nilai prioritas kedekatan relatif dari alternatif untuk solusi terbaik. Alternatif yang sudah diberi peringkat kemudian digunakan sebagai referensi bagi para pembuat keputusan untuk memilih solusi terbaik. Dengan metode tersebut dihasilkan sebuah penelitian yang menghasilkan sebuah aplikasi Sistem Penunjang Keputusan Pemilihan Motor bekas Untuk Masyarakat yang memiliki kemampuan untuk mendukung pengambilan keputusan pemilihan sepeda motor bekas, mempermudah dalam proses pemilihan sepeda motor bekas serta tentunya dapat dijadikan sebagai alat bantu dalam pengambilan keputusan.
\end{abstract}

Kata Kunci: Motor Bekas, Sistem Penunjang Keputusan, TOPSIS

\section{Abstract}

The need for transportation is something that is commonplace and is very much needed in life. One of the most widely used means of land transportation by people in Indonesia is motorcycle, because besides being economical compared to four-wheeled motorized vehicles, motorcycles have the advantage of being able to reach their destination faster. The method used is TOPSIS which will rank options based on the total priority value of the relative proximity of the alternatives for the best solution. The alternatives that have been ranked are then used as a reference for decision makers to choose the best solution. With this method produced a study that resulted in an application for a used motorcycle selection decision support system for people who have the ability to support decision making for the selection of a used motorcycle, simplify the process of selecting a used motorcycle and can certainly be used as a tool in decision making.

Keywords: Used Motorcycles, Decision Support Systems, TOPSIS

\section{Pendahuluan}

Transportasi merupakan suatu gerak perpindahan baik berupa suatu benda atau orang dari satu tempat ke tempat lain yang dituju.

Memilih dua diantara beberapa alternative merupakan suatu bentuk pengambila keputusan. Tindakan dengan perhitungan yang sistematis guna menentukan sebuah keputusan dari beberapa alternative yang ada. Pengambilan keputusan dari beberapa alternative pun bisa dilakukan dengan proses seleksi beberapa langkah yang spesifik (Musa \& Setiono, 2012).

Untuk mempermudah pengambilan keputusan dapat dilakukan dengan memberikan user interface yang mudah. ( (Turban, R, \& D, 2011)

Identifikasi masalah, Seleksi data relevan, pendekatan pengambilan keputusan serta evaluasi pengambilan keputusan dapat memanfaatkan system computer sebagai system penunjang pengambil keputusan. (De Christin \& Djamain, 2015) 
(Kusumadewi, 2006), TOPSIS adalah teknik pilihan multi-kriteria atau preferensi alternatif yang merupakan pilihan yang memiliki kemungkinan alternative solusi terbaik yang luar biasa dan jarak terbesar dari jawaban terbaik dari faktor geometris menurut pandangan penggunaan Euclidean Distance. Tetapi, pilihan yang mempunyai jarak terkecil dari solusi terbaik sehingga tidak harus memiliki jarak terbesar dari solusi terbaik yang negatif. Oleh karena itu, TOPSIS menghitung baik jarak ke solusi terbaik yang fantastis maupun jarak ke jawaban ideal yang buruk secara bersamaan. Jawaban yang paling diinginkan dalam metode TOPSIS diterima dengan bantuan mengidentifikasi kedekatan yang relatif dari alternatif untuk solusi terbaik berkualitas tinggi. TOPSIS akan menentukan peringkat pilihan berdasarkan biaya prioritas dari kedekatan relatif dari pilihan ke solusi sempurna berkualitas tinggi. Alternatif yang sudah diberi peringkat kemudian digunakan sebagai referensi para pengambil keputusan dalam memilih jawaban yang diinginkan.

Keinginan akan transportasi adalah sesuatu yang mutlak dalam kehidupan modern. Sarana transportasi, terutama kemampuan transportasi non-publik diperlukan oleh masyarakat untuk mengangkut berbagai kebutuhan hidup setiap hari. Salah satu alat transportasi darat yang paling banyak digunakan oleh masyarakat di Indonesia adalah sepeda motor, karena selain lebih irit jika dibandingkan dengan kendaraan bermotor roda empat, motor memiliki kelebihan bisa mencapai tempat tujuan lebih cepat. Berbagai produsen sepeda motor mengeluarkan banyak varian dan jenis yang beragam dan dengan keunggulannya masing-masing. Membeli motor baru sudah pasti harus memiliki dana yang tidak sedikit. Pada umumnya masyarakat kelas bawa kurang memiliki kemampuan untuk membeli sepeda baru tersebut sehingga dengan sangat terpaksa mereka mengalihkan perhatiannya kepada motor-motor bekas. Tetapi mereka dihadapkan kembali kepada permasalahan merk dan jenis motor apa yang akan dibelinya. Karena banyak kriteria atau pilihan yang harus diperhatikan didalam membeli sepeda motor bekas, diantaranya kelengkapan surat-surat kendaraan bermotor, harga, desain, kondisi sepeda motor, keaslian sparepart, dan keiritan bahan bakar.

Dari uraian diatas, maka penulis memiliki tujuan untuk lebih dalam meneliti penelitian yang berjudul, "Sistem Penunjang Keputusan Pemilihan Motor Bekas Untuk Masyarakat Menggunakan Metode TOPSIS".

Menurut (Chamid, 2016) pada penelitiannya yaitu Penerapan Metode Topsis untuk Menentukan Prioritas Kondisi Rumah, memberikan penjelasan tentang perhatian dinas kesehatan serta setiap warga negeri mengenai keadaan rumahnya. Untuk menentukan keadaan tempat tinggal apakah dinyatakan sehat atau tidak dengan memakai tiga kriteria, termasuk: komponen rumah, fasilitas perumahan, dan perilaku. Pendekatan TOPSIS digunakan untuk menentukan prioritas kondisi perumahan yang tidak sehat. Dari hasil perhitungan, dinyatakan bahwa pilihan ke-2 dengan biaya pilihan 1 menjadi prioritas utama bagi kondisi rumah yang dinyatakan tidak sehat. Serta hasil perhitungan ini dapat menindaklanjuti prioritas rumah yang tidak sehat dengan memasukannya ke dinas kesehatan.

Menurut (Wiguna \& Yuliana, 2016) dengan penelitian yang berjudul Sistem Makanan Menggunakan Metode Composite Performance Index (CPI) Berbasis Android pada Steak Hotel By Holycow Bandung, menerangkan mengenai Steak Hotel by Holycow yang merupakan restoran steak kualitas tinggi dengan harga yang terjaungkau. Pelanggan kerepotan ketika melakukan pemesanan makanan pada hotel tersebut. Kemudian belum adanya rekomendasi pilihan menu berdasarkan kriteria tertentu secara terurut bagi pelanggan. Aplikasi delivery order makanan berhasil dibangun menggunakan Android dengan metode Composite Performance Index. Algoritma CPI dapat membantu menentukan urutan rekomendasi menu berdasarkan kriteria seperti rating, best seller, dan harga tertinggi atau terendah (Wiguna \& Yuliana, 2016).

Menurut (Putra \& Epriyanto, 2017) pada penelitiannya yang berjudul Sistem Pendukung Keputusan Pemilihan Sepeda Motor Jenis Sport 150cc Berbasis Web Menggunakan Metode Analytical Hierarcy Process (AHP), menjelaskan kebingungan pelanggan dalam memilih motor sport yang sesuai kebutuhan dengan pilihan berbagai 
desain, harga serta konsumsi bahan bakar. (AHP menjadi salah satu pendekatan yang dapat digunakan dengan beberapa kriteria komparatif, khususnya desain, konsumsi bensin, roda gigi transmisi, harga, dan kapasitas tangki. Utilitas ini dibuat terutama berdasarkan internet penggunaan bahasa pemrograman PHP sebagai bahasa pemrograman dan database MySQL. Outputmya adalah untuk membantu membuat pilihan dalam menentukan sepeda motor sport mana yang sesuai untuk pelanggan berdasarkan kriteria yang diinginkan (Putra \& Epriyanto, 2017).

\section{Metode Penelitian Metode TOPSIS}

Technique For Order Preference by Similarity to Ideal Solution atau lebih dikenal dengan singkatan TOPSIS adalah salah satu dari Kriteria multak atau strategi pengambilan keputusan berdasarkan pilihan alternatif yang memiliki jarak terkecil dari jawaban sempurna yang indah dan jarak terbesar dari jawaban sempurna yang mengerikan dari suatu perspektif geometris penggunaan Euclidean distance. Namun, pilihan yang memiliki jarak terkecil dari solusi ideal yang efektif, tidak lagi harus memiliki jarak terbesar dari solusi terbaik yang buruk. Oleh karena itu, TOPSIS menganggap masing-masing jarak ke solusi terbaik positif dan jarak ke jawaban sempurna yang sulit secara bersamaan. Jawaban yang paling memuaskan dalam teknik TOPSIS diterima dengan menggunakan kedekatan yang relatif dari pilihan ke solusi terbaik berkualitas tinggi. TOPSIS akan menentukan peringkat opsi berdasarkan total pada nilai prioritas kedekatan relatif dari alternatif untuk solusi terbaik yang terbaik. Alternatif yang sudah diberi peringkat kemudian digunakan sebagai referensi bagi para pembuat keputusan untuk memilih solusi terbaik (Sachdeva, Kumar, \& Kumar, 2019)

Berikut ini langkah-langkah teknik topsis :

a. Bangun matrik pilihan. Matrik $X$ (keputusan) mengacu pada pilihan $\mathrm{m}$ yang akan dievaluasi terutama berdasarkan pada kriteria $\mathrm{n}$.

b. Buatlah matrik pilihan yang dinormalisasi.

c. Buat matrik keputusan yang menormalkan terbobot.

d. Tentukan matrik jawaban sempurna yang luar biasa dan solusi sempurna yang buruk. e. Hitung pemisahan f. Menghitung kedekatan dengan solusi ideal yang luar biasa.

\section{g. Peringkat alternatif. \\ Kosep Dasar Program}

Menurut (Kadir, 2012) Program ialah serangkaian instruksi yang berguna untuk mengatur pengoperasian komputer dengan pasti. Tanpa program, komputer yang sebenarnya tidak bisa melakukan fungsinya. Itu mengapa sering dinyatakan bahwa sistem komputer memiliki tiga aspek penting, dalam bentuk hardware dan software yang dalam hal ini berbentuk program, dan inventif (brainware) atau orang yang berperan dalam mengoperasikannya dan pengembangannya. Dengan kata lain, perangkat lunak adalah salah satu komponen penting dari komputer yang mengatur sehingga melakukan tindakan yang sesuai dengan keinginan pabrikan.

Visual Basic merupakan bahasa pemrograman komputer yang perintah atau praktiknya dapat dipahami untuk melakukan tugas tertentu dalam program. Selain disebut sebagai bahasa pemrograman, pada dasarnya sering juga disebut sebagai tools untuk menghasilkan program utilitas berbasis system operasi windows. Beberapa kemampuan dan kelebihan dari visual basic terlihat meliputi:

a. Membuat perangkat lunak berbasis windows.

b. Membuat objek ActiveX, Help file, web, dan sebagainya.

c. Pengujian program (debugging) dan hasilkan perangkat lunak final dengan ekstensi EXE yang dapat dieksekusi atau dapat dijalankan tanpa penundaan.

\section{Hasil dan Pembahasan}

\subsection{Analisis}

\subsubsection{Analisis Masalah}

Dari hasil analisa yang penulis lakukan, masih banyak konsumen yang masih bingung dalam memilih motor bekas, terutama dalam beberapa kriteria seperti kelengkapan surat-surat kendaraan bermotor, harga, desain, kondisi sepeda motor, keaslian sparepart, dan keiritan bahan bakar.

\subsubsection{Analisis Kebutuhan Pengguna

$$
\text { Berdasarkan hasil observasi }
$$

diskusi dengan para penjual dan 
konsumen, penulis dapat mengidentifikasi kebutuhan dari pengguna, yaitu:

a. Membuat sebuah aplikasi Sistem Penunjang Keputusan pemilihan motor bekas untuk masyarakat agar dapat membantu mnegambil keputusan dengan efektif dan efisien.

b. Mempermudahdan mempercepat transaksi pemrosesan pemilihan motor bekas.

\subsubsection{Analisis Perangkat Lunak}

Spesifikasi minimal komputer sebagai berikut:

Tabel 1. Analisa Kebutuhan System

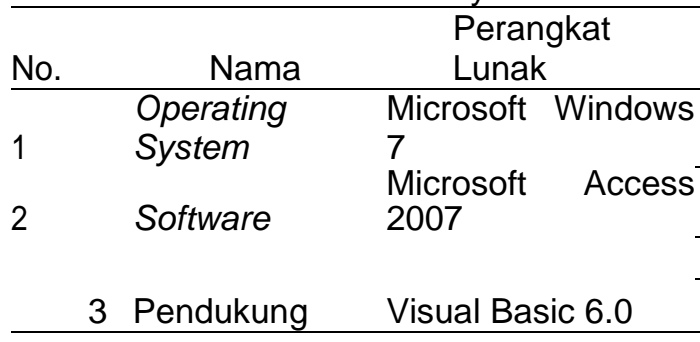

\subsubsection{Analisa Perangkat Keras}

Persyaratan minimal software komputer yang dibutuhkan untuk membuat sistem ini adalah:

Tabel 2. Kebutuhan Perangkat Keras

\begin{tabular}{lll}
\hline No. & \multicolumn{1}{c}{ Item } & Spesifikasi \\
\hline 1 & Prosesor & $2,4 \mathrm{GHz}$ \\
2 & RAM & $1 \mathrm{~GB}$ \\
3 & Harddisk & $60 \mathrm{~GB}$ \\
4 & Monitor & 14 inchi \\
5 & LAN Card & Onboard \\
\hline
\end{tabular}

\subsection{Perancangan}

\subsubsection{Rancangan Algoritma}

Metode TOPSIS memiliki langkah kerja sebagai berikut:

a. Membuat matrik keputusan. Matrik keputusan $\mathrm{X}$ yang mengacu kepada $\mathrm{m}$ alternatif yang akan dievaluasi sesuai nilai $n$ kriteria. Matrik $X$ dapat digambarkan sebagai berikut:

$\begin{array}{llllll}x_{1} & x_{2} & x_{3} & \cdot & x_{n}\end{array}$

$\mathrm{X}=\left[\begin{array}{ccc}x_{11} & \cdots & x_{n 1} \\ \vdots & \ddots & \vdots \\ x_{m 1} & \cdots & x_{m n}\end{array}\right]$

Keterangan :

ai $=$ alternative yang mungkin

$\mathrm{xj}=$ atribut yang mengukur performansi alternative $\mathrm{xij}=$ performansi alternative ai dengan atribut sebagai parameter

b. Normalisasi dibuat setelah matrik keputusan. Persamaan yang dipakai untuk merubah setiap elemen $\mathrm{x}$, $\mathrm{i}$ dan $\mathrm{j}$ adalah:

$$
r_{i j}=\frac{-x_{i j}}{\sqrt{\sum_{i=1}^{m} x_{i j}^{2}}}
$$

$\mathrm{i}=1,2,3, \ldots ., \mathrm{m}$;

$\mathrm{j}=1,2,3, \ldots \ldots, \mathrm{n}$;

\section{Keterangan :}

rij $r$ dinormalisasi oleh elemen matrik keputusan,

xij matrik keputusan $x$ dari elemen.

c. Normalisasi terbobot dari matrik keputusan.

Dengan bobot wj yang merupakan bobot dari kriteria ke-j

$\operatorname{dan} \sum_{j=1}^{n} w_{j}$,

maka bobot matrik $V$ yang dinormalisasi adalah $V_{i j}=W_{i} X r_{i j}$

$$
\begin{aligned}
& i=1,2,3, \ldots \ldots . ., m ; \\
& j=1,2,3, \ldots \ldots ., n .
\end{aligned}
$$

Keterangan:

Elemen dari matrik keputusan setelah dinormalisai terbobot $\mathrm{V}$, yang merupakan bobot kriteria ke-j adalah elemen dari matrik keputusan yang sudah dinormalisasi R.

d. Menentukan matrik solusi yang ideal dan positif serta solusi ideal yang negatif. Solusi ideal positif dinotasikan dengan $\mathrm{A}^{+}$, sedangkan solusi ideal negative dapat dilambangkan $\mathrm{A}^{-}$dengan persamaan sebagai berikut:

$$
\begin{aligned}
A^{+} & =\{(\max y i j \mid j \in \\
J) & \left.\left(\min y i j \mid i \in J^{\prime}\right), i=1,2,3, \ldots, m\right\} \\
& =\{v 1-, v 2-, v 3-, \ldots, v n-\} \\
A^{-} & =\{(\min y i j \mid j \in \\
J), & \left.\left(\max y i j \mid i \in J^{\prime}\right), i=1,2,3, \ldots, m\right\} \\
& =\{v 1-, v 2-, v 3-, \ldots, v n-\} \\
J \quad & =\{j=1,2,3, \ldots, n\} \text { dan } J
\end{aligned}
$$


merupakan himpunan kriteria keuntungan (benefit criteria).

$J^{\prime}=\{j=1,2,3, \ldots, n\}$ dan $J^{\prime}$ merupakan himpunan kriteria biaya (cost criteria).

Keterangan:

$V_{i j}$ Adalah elemen dari matriks keputusan yang telah dinormalisasi terbobot $\mathrm{V}$

$\mathrm{V}_{\mathrm{j}+}(\mathrm{j}=1,2,3, \ldots \ldots ., \mathrm{n})$ adalah elemen matriks solusi ideal positif

$\mathrm{V}_{\mathrm{ji}}(\mathrm{j}=1,2,3, \ldots \ldots ., \mathrm{n})$ adalah elemen matriks solusi ideal negatif

\section{e. Menghitung separasi}

S+ merupakan jarak alternative dari solusi ideal positif yang dinotasikan dengan :

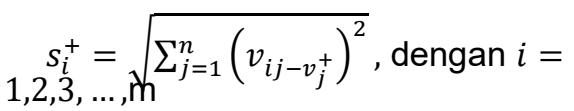

S- merupakan jarak alternative dari solusi ideal negative yang dinotasikan dengan :

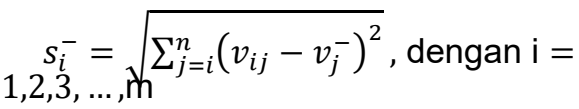

Keterangan:

$\mathrm{Si}_{+} \quad$ Solusi ideal positif yang merupakan alternative jarak ke-l.

Si- solusi ideal negatif yang merupakan alternative jarak ke-I.

vij Merupakan elemen keputusan yang terbobot variabel $\mathrm{V}$.

vj+ Matrik dari solusi ideal positif.

vj- $\quad$ Matrik darisolusi ideal negatif.

f. solusi ideal positif yang dapat dihitung kedekatannya dengan persamaan berikut

$$
\mathrm{c}_{\mathrm{i}}^{+}=\frac{\mathrm{s}_{\mathrm{i}}^{-}}{\left(\mathrm{s}_{\mathrm{i}}^{-}+\mathrm{s}_{\mathrm{i}}^{+}\right)}, 0 \leq \mathrm{c}_{\mathrm{i}}^{+} \leq 1
$$

g. Memeringkatkan alternatif.

Alternative diurutkan mulai dari nilai $\mathrm{C}^{+}$ paling besar ke nilai yang paling kecil. Alternatif dengan nilai $\mathrm{C}^{+}$paling besar adalah solusi terbaik.

\subsubsection{Rancangan Database}

\section{Perancangan Entity}

Relatioship

Diagram (ERD) dilakukan untuk mengetahui hubungan antar table pada database. Dalam aplikasi ini terdapat satu database yang bernama SPK yang memiliki tabel yang saling berhubungan, dibawah ini adalah gambar ERD dari system yang dirancang :

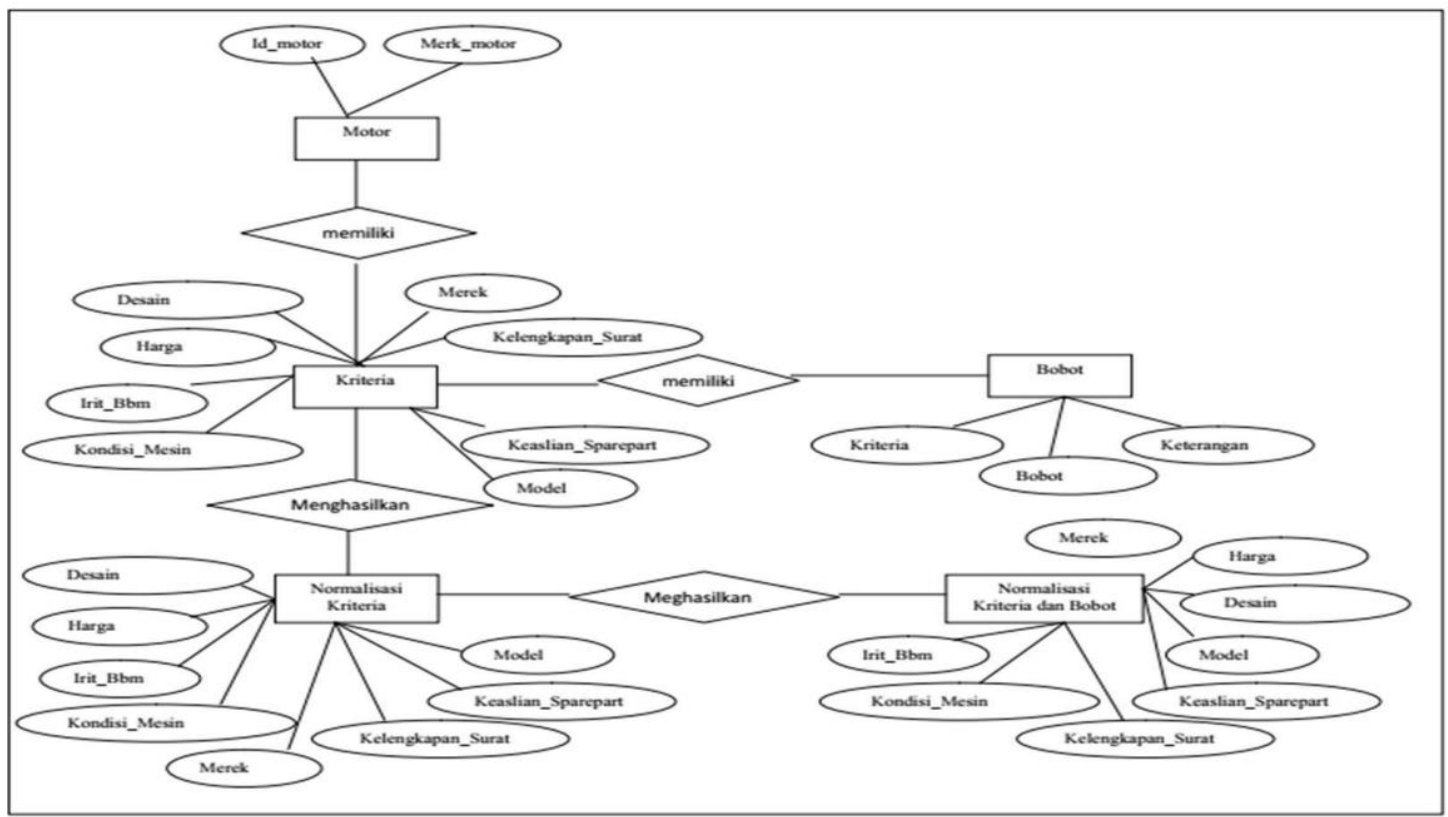

Gambar 1. ERD Pemilihan Motor Bekas 
4.2.3 Unified Modelling Language (UML)

a. Use Case Diagram

1) Admin

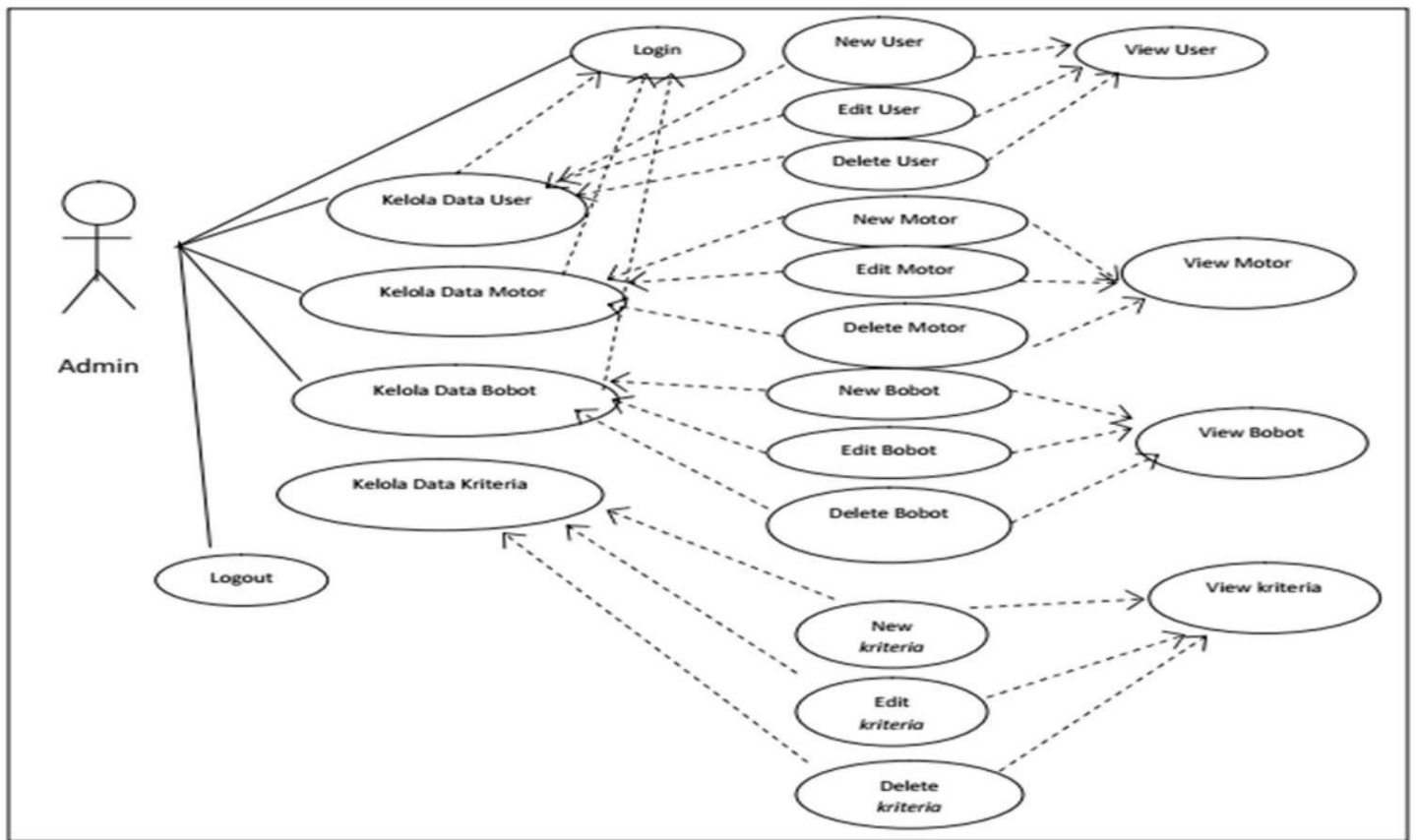

Gambar 2. Use Case Diagram Admin

2)Pengguna

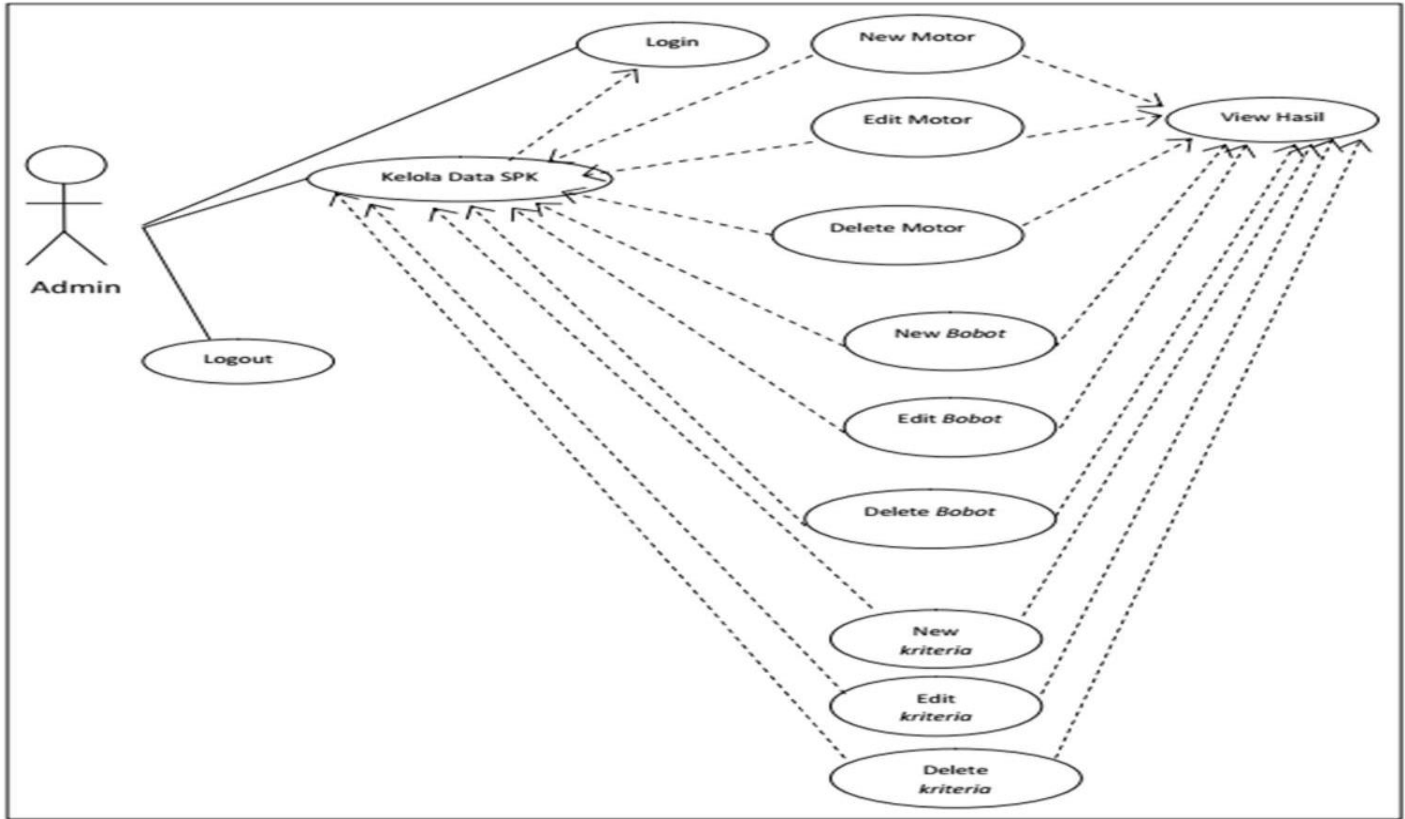

Gambar 3. Use Case Diagram Pengguna 
b. Activity Diagram

1) Kelola Data User

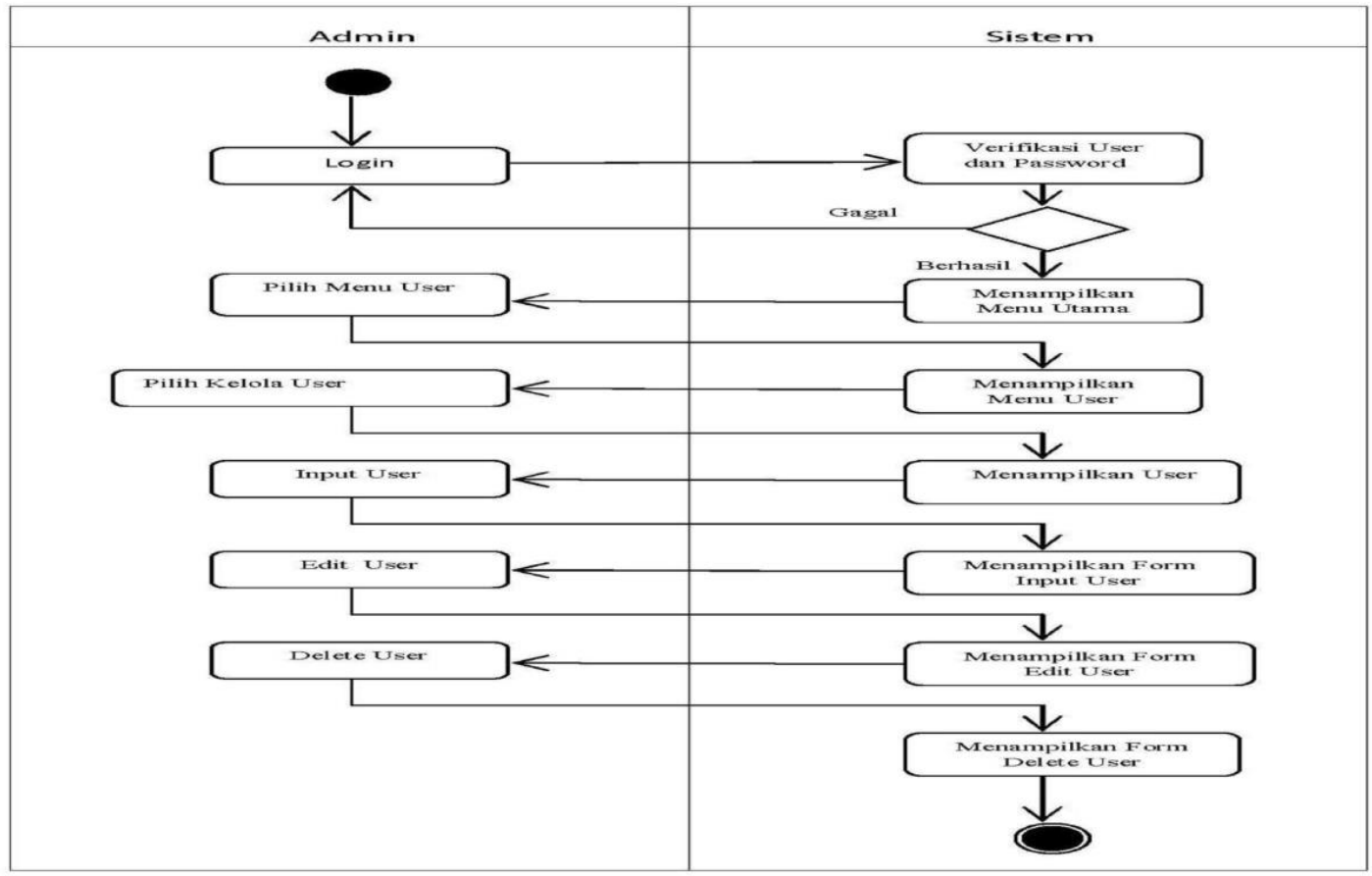

Gambar 4. Activity Diagram Kelola Data User

2) Kelola Data Motor

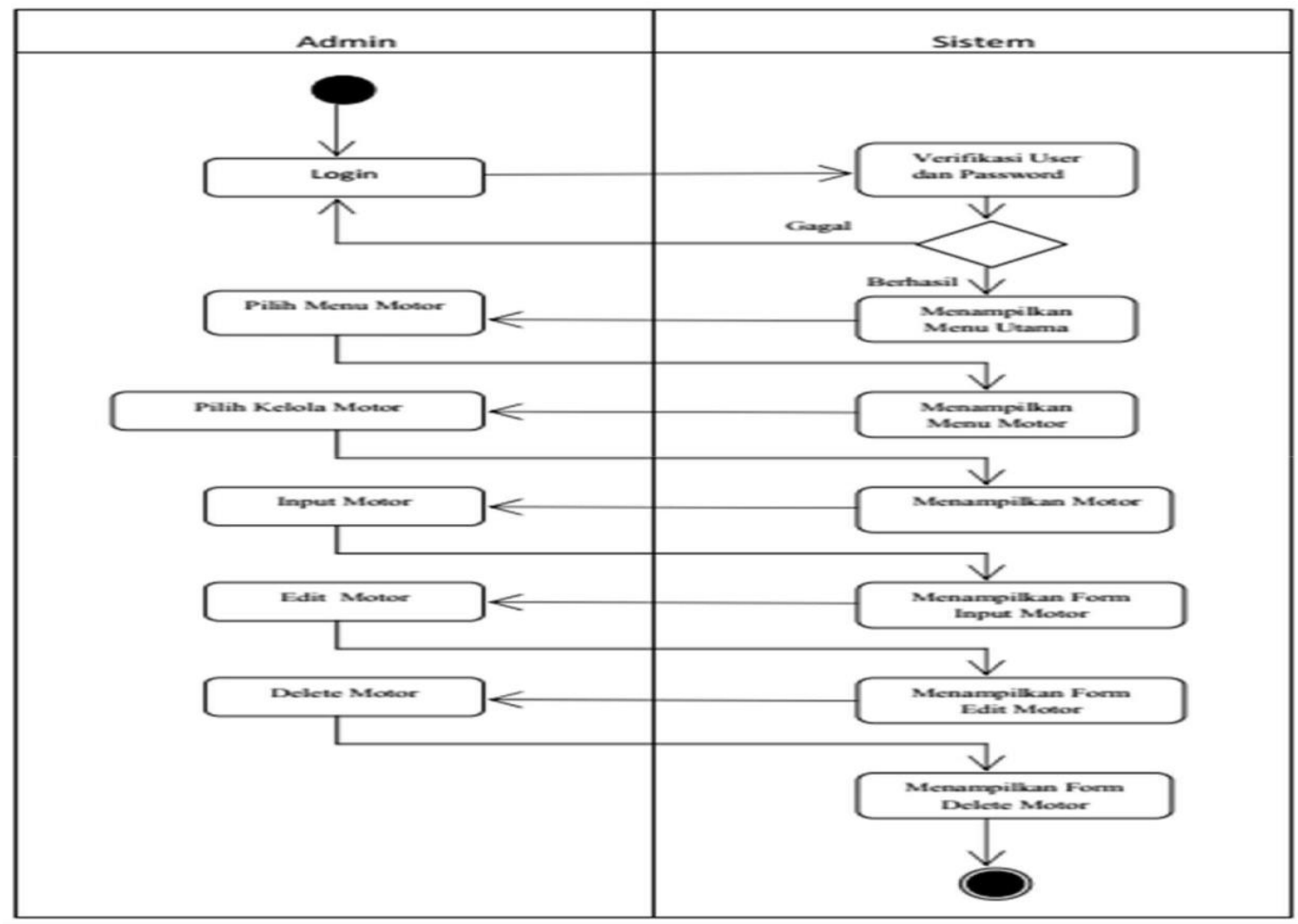

Gambar 5. Activity Diagram Kelola Data Motor 
3) Kelola Data Bobot

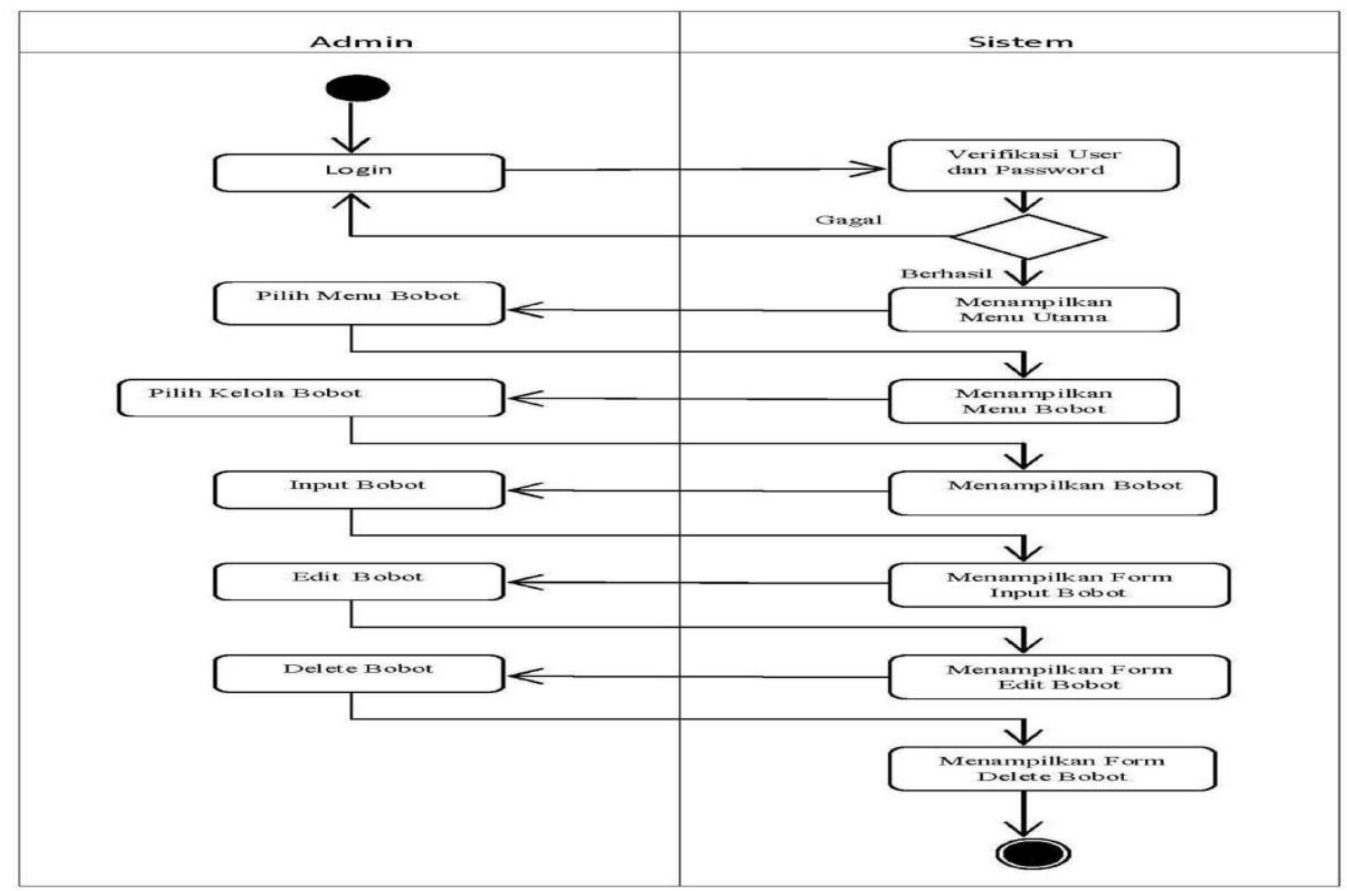

Gambar 6. Activity Diagram Kelola Data Bobot

4) Kelola Data Kriteria

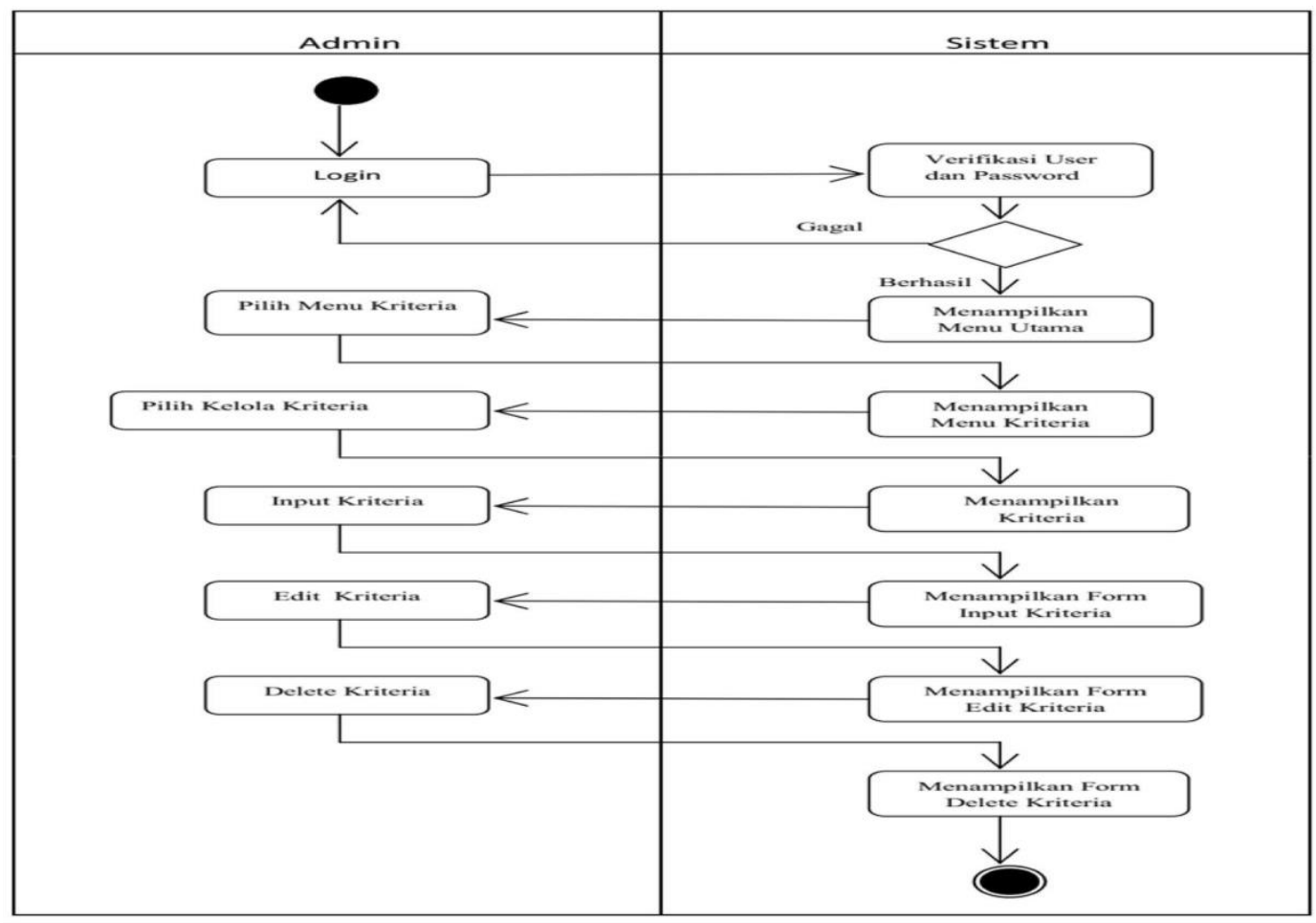

Gambar 7. Activity Diagram Kelola Data Kriteria 
5) Pemilihan Motor Bekas

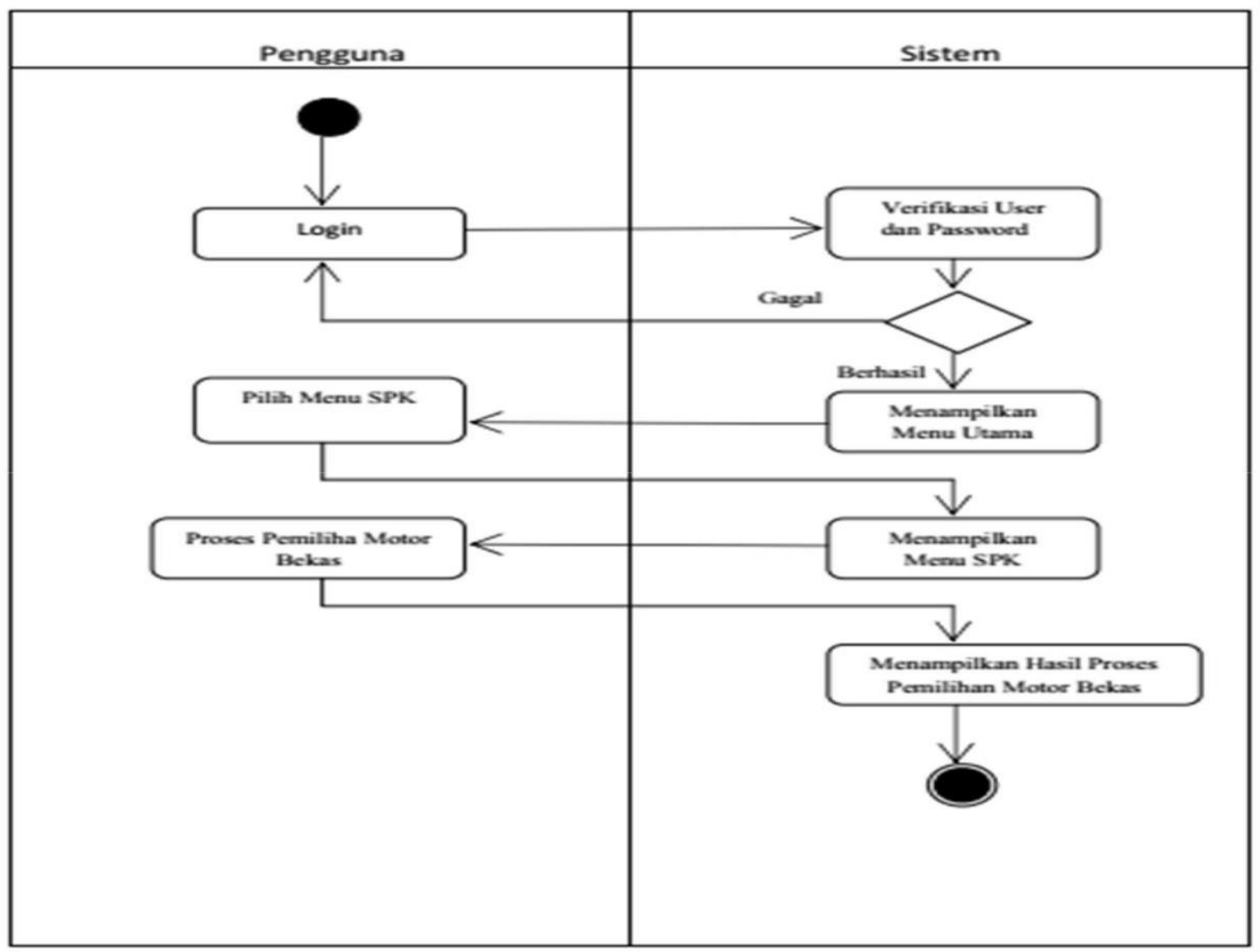

Gambar 8. Activity Diagram

\section{Kesimpulan}

Dalam penelitian ini penulis membahas mengenai Sistem Penunjang Keputusan Pemilihan Motor Bekas Untuk Masyarakat Menggunakan Metode TOPSIS. Berdasarkan hasil pemaparan diatas maka dapat diambil kesimpulan, yaitu :

a. Aplikasi memiliki kemampuan untuk mendukung pengambilan keputusan pemilihan sepeda motor bekas.

b. Aplikasi ini mempermudah dalam proses pemilihan sepeda motor bekas bagi masyarakat.

c. Aplikasi pemilihan sepeda motor bekas ini dapat dijadikan oleh masyarakat sebagai alat bantu dalam pengambilan keputusan.

\section{Referensi}

Chamid, A. A. (2016). Penerapan Metode TOPSIS Untuk Menentukan Prioritas Kondisi Rumah. Simetris: Jurnal Teknik Mesin, Elektro dan IImu Komputer, 537-544.
De Christin, H., \& Djamain. (2015). Sistem Pendukung Keputusan Penerimaan Pegawai Baru PT. PLN (Persero) Kantor Pusat dengan Menggunakan Metode Simple Additive Weighting (SAW). Jurnal Teknologi dan Informasi (JATI).

Kadir, A. (2012). Algoritma \& Pemrograman Menggunakan Java. Yogyakarta: Andi Offset.

Kamaludin, R. (1986). Ekonomi Transportasi. Jakarta: Ghalia Indonesia.

Kusumadewi. (2006). Fuzzy Multi Attribute Decision Making. Yogyakarta: Graha IImu.

Musa, \& Setiono. (2012). Pengaruh Moda Transportasi Darat terhadap Kelancaran Arus Container di PT. Nilam Port Terminal Indonesia Cabang Tanjung Perak Surabaya. Jurnal Aplikasi Pelayaran dan Kepelabuhan.

Putra, D., \& Epriyanto, M. (2017). Sistem Pendukung Keputusan Pemilihan Sepeda Motor Jenis Sport 150cc 
Berbasis Web Menggunakan Metode Analytical Hierarcy Process (AHP). Jurnal Teknolf.

Sachdeva, A., Kumar, D., \& Kumar, P. (2019). Multi-Factor Failure Mode Critically. IEEE.

Turban, R, S., \& D, D. (2011). Decision Support and Business. New Jersey: Pearsson.

Wiguna, W., \& Yuliana, N. (2016). Sistem Delivery Order Makanan Menggunakan Metode Composite Performance Index (CPI) Berbasis Android Pada Steak Hotel By Holycow Bandung. Simposium Nasional IImu Pengetahuan dan Teknologi (SIMNASIPTEK), 122128. 